\title{
Pola Komunikasi Pelayanan Customer Service Bank Jabar-Banten Selama Pandemi Covid-19
}

\author{
Agia Dwi Vici Utami ${ }^{*}$, Dasrun Hidayat ${ }^{2}$, Suci Nujiana ${ }^{3}$, Mega Mutia Maeskina ${ }^{4}$ \\ Universitas Adhirajasa Reswara Sanjaya ${ }^{1,2,4}$, Universitas Subang ${ }^{3}$ \\ *Email : agiadvu@gmail.com
}

Diterima : 1 Oktober 2021

Disetujui : 25 Januari 2022

Diterbitkan : 25 Februari 2022

\begin{abstract}
Abstrak
Penelitian ini berfokus pada mengeksplorasi perubahan pola komunikasi pelayanan Customer Service selama pandemi Covid-19. Adanya perubahan pola komunikasi pelayanan Customer Service selama pandemi Covid-19 menjadi latar belakang permasalahan sehingga diperlukan kajian terkait pola komunikasi kerja pelayanan Customer Service selama pandemi Covid-19. Tujuan penelitian yakni menganalisis segala bentuk perubahan dan pola komunikasi dalam pelayanan Customer Service selama pandemi Covid-19. Metode kualitatif yang digunakan pada penelitian ini dengan pendekatan studi kasus (case study). Melibatkan dua Customer Service dan tiga nasabah sebagai informan. Adapun teknik pengumpulan data yakni reduksi data, penyajian data dan simpulan (verifikasi data). Hasil penelitian ini menemukan tiga perbedaan pola komunikasi pelayanan Customer Service selama pandemi Covid-19 yang meliputi, perubahan pola tata letak ruang (layout) yang meliputi area kerja customer service, perubahan jam operasional kerja selama pelayanan berlangsung dan penambahan atribut Customer Service sesuai dengan protokol kesehatan.
\end{abstract}

Kata Kunci: Covid-19, Komunikasi, Pelayanan, Perbankan

\begin{abstract}
This study focuses on exploring the changing of the way of Customer Service works during the Covid-19 pandemic. The change in the Customer Service mechanism during the Covid-19 pandemic became the background of the problem, therefore a study was needed regarding the working mechanism of Customer Service during the Covid-19 pandemic. The purpose of the study was to analyze all forms of change and communication patterns in Customer Service services during the Covid-19 pandemic. The qualitative method used in this research is a case study approach. Involving two Customer Service and three customers as informants. The data collection techniques are data reduction, data presentation and conclusions (data verification). The results of this study found three differences in the mechanism of Customer Service during the Covid-19 pandemic which included changes in the layout of the room, changes in working hours and Customer Service attributes. The results of this study, researchers hope to contribute to improving the business of the banking sector and improve Customer Service hence that there is no miscommunication does not occur in the next time.
\end{abstract}

Keywords: Covid-19, Communication, Service, Bank 


\section{PENDAHULUAN}

Dalam bidang ekonomi pada sektor perbankan, komunikasi dan informasi menjadi salah satu kegiatan yang menunjang keberlangsungan aktivitas antara pihak bank dengan masyarakat atau yang disebut sebagai nasabah. Contoh nyata penggambaran aktivitas komunikasi dan informasi yang dilakukan di bank adalah interaksi antara Customer Service dengan nasabah atau masyarakat dalam berbagai urusan perbankan. Perusahaan yang bergerak dalam sektor perbankan menerapkan, memperlihatkan dan menonjolkan bahwa pelayanan harus dapat menunjang dan memberikan perhatian kepada nasabahnya. Sektor perbankan sangat membutuhkan peran pelayanan sebagai Customer Service.

Memberikan informasi berupa pelayanan produk perbankan atau seluruh produk yang mencakup aktivitas perbankan seorang Customer Service menduduki peran utama yang menjalani peran dalam sebuah bank, dimana Customer Service berhadapan langsung dengan nasabah atau masyarakat dalam menjalankan proses pelayanan informasi terkait perbankan atau layanan-layanan sejenis lainnya. "Customer Service ialah seorang pertugas atau karyawan yang dibentuk dan diberi tugas untuk melayani nasabah oleh industri sektor keungan diantaranya sektor perbankan, leasing atau asuransi”. Untuk itu proses komunikasi dan transfer informasi dalam hal ini menjadi penunjang keberlangsungan pelayan antara Customer Service dan nasabah.

Teknik penyampaian informasi atau cara berkomunikasi antara Customer Service dan nasabah umunya dilakukan secara tatap muka atau langsung. Sehingga dapat memaksimalkan proses komunikasi yang dilakukan keduanya (Customer Service dan nasabah) berlangsung secara optimal dan menghindari adanya misscomunication antara pihak bank dengan nasabah. Sehingga memberhasilkan proses pelayanan bank kepada nasabahnya. Customer Service harus dapat selalu menjalin hubungan yang baik dengan nasabah baru maupun lama agar mendapatkan sebuah kesepakatan dan solusi yang saling menguntungkan bagian kedua belah pihak, hal ini sesuai dengan teori Customer Relations menurut Newell yaitu segala kegiatan yang dilakukan perusahaan untuk mempertahankan konsumen yang sudah ada atau konsumen yang sudah menjadi pelanggan tetap (Mustika, 2017).

Proses komunikasi yang dilakukan secara tatap muka pihak bank dengan nasabah pada saat pandemi Covid-19 mengalami perubahan. Pasalnya keputusan menteri kesehatan yang mengharuskan menggunakan masker dan menerapkan protokol kesehatan. Hal ini sudah di atur dalam keputusan Menteri Kesehatan Republik Indonesia Nomor HK.01.07/MENKES/382/2020 tentang Protokol Kesehatan Bagi Masyarakat di Tempat dan Fasilitas Umum Dalam Rangka Pencegahan dan Pengendalian Covid-19 (Corona Virus Disease 2019) (Handayani et al., 2020). Fenomena ini dikhawatirkan menjadi hambatan dalam proses pola komunikasi pelayanan dan berakibat tidak berlangsung secara maksimal. Sehingga terjadinya penurunan pelayanan bank yang akan berpengaruh terhadap perkembangan bisnis pada sektor perbankan. Salah satu contoh kasus yang terjadi saat pelayanan Customer Service (komunikator) munculnya kesalah pahaman informasi yang diberikan oleh Customer Service kepada nasabah (komunikan) (Silalahi, 2020). Kesalahpahaman tersebut berupa tidak maksimalnya suara yang diterima oleh nasabah karena penggunaan masker sehingga suara Customer Service tidak jelas atau samar, mimik 
muka yang tidak terlihat sehingga memunculkan kesalahpahaman prasangka dan praduga dari respon Customer Service terhadap nasabah selama pelayanan.

Penelitian sebelumnya yang terkait dengan komunikasi pelayanan Customer Service menjadi bahan pembanding dan penunjang penyelesaian penelitian ini. Diantara nya yaitu penelitian pertama, mengenai Hubungan Kredibilitas Customer Service Dengan Kepuasan Nasabah Bank Mandiri KCP Bandung Antapani (Resi, 2016) dan penelitian berjudul Customer Relationship Management: A Case Study Of A Greek Bank (Blery \& Michalakopoulos, 2006). Perbedaan penelitian ini dan dua penelitian sebelumnya adalah terletak pada titik fokus penelitian yakni jika pada dua penelitain sebelumnya membahas tentang pelayanan Customer Service di bank sebelum pandemi Covid-19 sementara kajian ini akan membahas tentang pola komunikasi pelayanan Customer Service selama pandemi Covid-19. Aktivitas komunikasi pelayanan Customer Service dan nasabah disebut komunikasi antarpribadi, didalam komunikasi antarpribadi tersebut terdapat komunikator dan komunikan adapula pesan yang disampaikan (Hidayat, 2012). Customer Service berperan sebagai komunikator seseorang yang menyapaikan pesan atau informasi dan nasabah sebagai komunikan seseorang yang menerima pesan. Pada kemampuan atau skill Customer Service dituntut untuk menjalin hubungan baik yang disebut customer relations.

Berdasarkan penjelasan pada latar belakang masalah maka penelitian berfokus pada bagaimana pola komunikasi pelayanan Customer Service selama pandemi Covid-19, penelitian ini bertujuan untuk menganalisis pola komunikasi pelayanan Customer Service selama pandemi Covid-19. Adapun aspek yang dikaji untuk menjawab tujuan tersebut meliputi tata letak (layout), jam operasional dan penggunaan APD dalam penerapan protokol kesehatan selama melakukan pelayanan pada masa atau pandemi Covid-19. Diharapkan hasil penelitian ini mampu berkontribusi terhadap proses komunikasi pelayanan selama pandemi Covid-19.

\section{METODOLOGI PENELITIAN}

Penelitian ini mengkaji tentang pola komunikasi pelayanan Customer Service bank Jabar-Banten selama pandemi Covid-19. Selanjutnya, objek dari penelitian ini adalah komunikasi pelayanan Customer Service bank Jabar-Banten selama pandemi Covid-19. Metode yang digunakan yakni metode penelitian kualitatif dan menggunakan pendekatan studi kasus (case study). Metode ini dapat digunakan untuk mengetahui dan memahami fenomena yang minim atau yang belum diketahui tentang pelayanan Customer Service selama pandemi Covid-19. Penelitian kualitatif dapat melihat sebuah fenomena dapat berubah-ubah dan memiliki dinamika tersendiri karena perbedaan persepsi masing-masing individu. Memahami dan memandang dari sudut pandang orang lain yang mengalami nya (first-hand experience).

Studi kasus (case study) diperoleh dari pihak-pihak yang bersangkutan, data dapat dikumpulkan dari berbagai sumber dan sudut pandang sumber yang berbeda. Jika dipusatkan salah satu aspek atau salah satu narasumber saja akan kurang kedalamannya tentang kasus tersebut. Studi kasus akan kehilangan arti jika hanya menjelaskan gambaran umum saja, tanpa mempelajari aspek khusus secara intensif dan mendalam. Dengan begitu, studi kasus 
tidak dapat diperoleh dari subjek penelitian saja, tetapi diperoleh dari semua pihak yang mengerti dan mengetahui akan hal kasus tersebut (Raharji, 2017). Alasan peneliti menggunakan pendekatan studi kasus karena fenomena pelayanan Customer Service selama pandemi Covid-19 yang mengharuskan menerapkan protokol kesehatan dinilai sebagai kasus yang unik dan belum ada kajian spesifik sebelumnya.

Informan atau subjek penelitian ini ditentukan berdasarkan kriteria yang sudah dibuat diantaranya 2 (dua) orang Customer Service dengan syarat (1) Seseorang yang bekerja aktif sebagai Customer Service di bank BJB KCP RSI Al-Ihsan; (2) Menerapkan protokol kesehatan pada saat melakukan proses pelayanan Customer Service; (3) Customer service yang sudah bekerja lebih dari enam bulan selama pandemi Covid-19. Dan 3 (tiga) orang nasabah dengan syarat (1) Nasabah bank BJB aktif dan sering melakukan transaksi offline setidaknya satu bulan satu kali; (2) Nasabah yang mengunjungi bank BJB (pelayanan Customer Service) lebih dari 5 kali selama pandemi Covid-19. Wawancara penelitian ini dilakukan pada bulan Juli 2021.

Teknik pengumpulan data pada penelitian ini dilakukan dengan cara observasi, wawancara lanjutan dan dokumentasi. Bertujuan agar mendapatkan hasil atau data primer. Observasi dilakukan secara langsung dengan meneliti lokasi tempat penelitian. Pada teknik ini, peneliti melihat dan mengamati dengan cermat, serta menangkap dan merekam kegiatan perilaku dengan seksama, yang berkaitan dengan pelaku, tempat, kegiatan, ruang, bendabenda, peristiwa, dan waktu. Peneliti melihat, mengamati dan mencermati perilaku Customer Service dan nasabah selama pelayanan berlangsung di Bank BJB KCP RSI Al-Ihsan. Wawancara dilakukan secara online dengan menggunakan vitur media sosial WhatsApp kepada informan, teknik ini merupakan pertemuan yang bertujuan untuk bertukar ide atau informasi berupa tanya jawab yang dapat dikonstruksikan menjadi satu topik tertentu. Dalam wawancara ini peneliti mendapatkan persepsi, pola pikir dan sikap dari informan atau narasumber terhadap sesuatu permasalahan yang di teliti.

Pengolaan data dilakukan dengan cara mereduksi data, yakni merangkum, memfokuskan pada hal penting, memilih dan mencari pola selanjutnya serta menghapus yang tidak dibutuhkan disebut dengan reduksi data. Data yang telah di proses reduksi akan menghasilkan data yang lebih jelas. Maka selanjutnya peneliti akan lebih mudah dalam pengumpulan data di proses selanjutnya. Media dan tools yang dapat digunakan oleh peneliti dalam proses ini diantara nya peralatan elektronik seperti komputer, untuk merekap data yang dihasilkan sehingga peneliti akan memaparkan data yang diperoleh dari objek penelitian yakni penelitian Customer Service selama pandemi Covid-19. Pada penelitian ini penyajian data menggunakan atau dilakukan dalam bentuk hubungan antar target yang di uraikan dengan bagan. Pada teknik Miles dan Huberman tools yang sering digunakan dalam proses penyajian data terutama dalam penyajian penelitian kualitatif yakni teks naratif (Ajif, 2013). Namun dalam ini peneliti menyajikan data yang telah diperoleh dari lokasi dan objek penelitian dengan cara mendeskripsikan hasil penelitian pelayanan Customer Service selama pandemi Covid-19. Langkah untuk menarik kesimpulan dalam analisis data kualitatif adalah verifikasi. Pada kesimpulan akan mendapatkan yang bersifat sementara dan memungkinkan dapat berubah jika pada proses selanjutnya tidak menemukan bukti yang cukup kuat dan dapat mendukung terhadap proses berikutnya. Namun jika kesimpulan yang di dapat diawal 
memiliki bukti yang dinyatakan valid serta konsisten pada saat peneliti melakukan konfirmasi ulang data ke lapangan maka hasil kesimpulan ini merupakan kesimpulan yang bersifat kredibel. Pada hal ini peneliti mendapat kesimpulan dari hasil data yang diperoleh dari objek penelitian yakni komunikasi harus tetap berlangsung dengan baik dalam pelayanan Customer Service selama pandemi Covid-19.

\section{HASIL DAN PEMBAHASAN}

Proses komunikasi pelayanan Customer Service selama pandemi Covid-19 ditemukan adanya perbedaan. Pelayanan di Bank BJB pada saat sebelum pandemi dan selama pandemi mengalami banyak perubahan, terutama dari sisi jam operasional dan perubahan atribut. Berikut hasil penelitian dari pola komunikasi pelayanan Customer Service selama pandemi Covid-19.

Perubahan pertama adalah perubahan tata letak (layout) bank BJB selama Pandemi Covid-19. Perbedaan yang signifikan terlihat di berbagai ruangan dimana kondisi satu bagian dengan bagian lainnya terdapat skat atau pembatas antar area pelayanan di bank seperti antar bilik (cutomer service dan teller). Selain adanya pembatas antar bilik, perubahanpun terjadi pada kondisi tempat duduk atau kursi tempat nasabah menunggu. Setiap satu baris kursi tidak boleh di isi penuh dan diberi jarak antar nasabah satu dengan nasabah lainnya atau mengosongkan setiap kursi dibagian genap. Hal ini menunjukan bahwa pelayanan dan tata letak berubah ketika diterapkannya protokol kesehatan. Jika ditinjau dari hasil wawancara secara daring jenis protokol kesehatan yang dapat merubah teknis pelayanan adalah mempersingkat komunikasi. Hal lain disampaikan oleh informan.

Sebenarnya kebijakan yang dikantor itu sudah di batasi untuk di area backinghall hanya boleh 50\% nasabah jadi tidak boleh ada kerumunan, dibatasi jarak antar duduk nasabah minimal 2 meter, jadi satu tempat duduk isi satu tempat duduk kosong dan seterusnya. Untuk pelayanan CS dengan nasabah harus menggunakan acrylic jadi membatasi nasabah dengan karyawannya biar lebih aman. (Lies Anggi Puspita Dewi, O6 Juni 2021)

Kondisi terkait perubahan tata letak seperti tempat duduk juga diakui nasabah. Menurut Anggi perubahan penataan kursi disatu sisi diharuskan karena kebijakan untuk menjaga jarak, akan tetapi di sisi lain nasabah juga merasa tidak nyaman. Diakui Anggi, selama pandemi tidak jarang ia harus menunggu nomor antrian dari luar tanpa adanya tempat duduk.

Kalo menurut saya perubahan tata letak bikin ngga efektif buat nasabah, contoh kalo misalnya didalam bank nya udah penuh, saya harus nunggu diluar. Karna ngga dapet tempat duduk, sedangkan diluar juga kita kan berdiri, kadang kalo siang panas. Ini juga nyangkut kenyamanan nasabah juga sih. Tapi saya nggak bisa nolak juga karena aturan ini kebijakan dari pemerintah selama pandemi (Anggi Lestari, 12 Juli 2021).

Selain perubahan pada tata letak, perubahan juga terjadi pada mekanisme jam operasional bank BJB. Dari hasil wawancara ditemukan tidak sedikit informan mengeluhkan 
perubahan jam operasional ini menimbulkan antrian. Untuk menghindari antrian nasabah harus datang lebih awal.

Jam operasional juga ikut berubah sebelum pandemi kan mulai jam 08.30 - 14.30, tapi sekarang berubah jam operasional dari jam 08.30 - 12.00 soalnya bank BJB yang di Al-Ihsan itu termasuk area zona merah. (Lies Anggi Puspita Dewi, 06 Juni 2021). Pengurangan jam operasional berubah efeknya sering ngga dapet nomor antrian jadi pengambilan nomor antrian harus dari pagi, kadang juga nomor antriannya sudah abis. Jadi saya harus bolak-balik ke bank, terus permasalahan juga ngga langsung beres di satu waktu. (Fani Suryani, 12 Juli 2021)

Selain kedua perubahan di atas, pelayanan juga berubah dalam segi atribut Customer Service bank BJB. Perubahan ini juga diakui oleh Customer Service bank BJB KCP RSI AlIhsan Baleendah Kabupaten Bandung berikut ini.

Ya ada perubahan, kaya Customer Service tetep ngikutin standar pakaian kerja tapi menyesuaikan sama protokol kesehatan kaya anjuran pemerintah, Customer Service udah harus pake baju APD standar bank, masker medis, sarung tangan juga standar bank. (Anggia Anggraeni Wijayanti, 13 Juli 2021).

Perubahan atribut Customer Service diakui oleh para nasabah menimbulkan beberapa hambatan dalam komunikasi, misalnya suara kurang terdengar jelas, power suara jadi terdengar kecil sehingga situasi tersebut diakui membuat nasabah kurang nyaman.

Waktu yang saya alami sih kedengerannya suara CS jadi kecil, menurut saya itu penyebab nya karena pake masker juga kehalang acrylic di depan. (Vira Oktapinda, 14 Juli 2021).

Informan lainnya juga mersakan hal yang sama bahwa masker yang digunakan oleh Customer Service menjadi kendala dalam berkomunikasi.

Suaranya jadi mantul, ada suara beb-beb gitu jadi akhirnya nggak jelas didengarnya. (Anggi Lestari, 12 Juli 2021).

Tabel 1. Perubahan Pola Komunikasi Kerja Customer Service menurut Informan

\begin{tabular}{clccc}
\hline \multirow{2}{*}{ No } & \multicolumn{1}{c}{ Informan } & \multicolumn{2}{c}{ Perubahan Pola Komunikasi Customer Service } \\
& & Layout & Jam Operasional & Atribut \\
\hline 1 & Lies Anggi Puspita Dewi & $\sqrt{ }$ & $\sqrt{ }$ & $\sqrt{ }$ \\
2 & $\begin{array}{l}\text { Anggia Anggraeni } \\
\text { Wijayanti }\end{array}$ & $\sqrt{ }$ & $\sqrt{ }$ & $\sqrt{ }$ \\
3 & Fani Suryani & -- & $\sqrt{ }$ & - \\
4 & Anggi Lestari & $\sqrt{ }$ & $\sqrt{ }$ & - \\
5 & Vira Oktapinda & -- & -- & $\sqrt{ }$
\end{tabular}

Sumber : Hasil Penelitian, 2021 
Tabel 1 di atas menjelaskan secara ringkas bahwa menurut informan terjadi perubahan pola komunikasi kerja Customer Service yang terletak pada layout, jam operasional dan atribut.

Tabel 2. Temuan hambatan dalam pelayanan Customer Service menurut Informan

\begin{tabular}{|c|c|c|c|c|}
\hline \multirow{2}{*}{ No } & \multirow{2}{*}{ Informan } & \multicolumn{3}{|c|}{ Hambatan dalam pelayanan Customer Service } \\
\hline & & Layout & Jam Operasional & Atribut \\
\hline 1 & Lies Anggi Puspita Dewi & $\sqrt{ }$ & $\sqrt{ }$ & $\sqrt{ }$ \\
\hline 2 & $\begin{array}{l}\text { Anggia Anggraeni } \\
\text { Wijayanti }\end{array}$ & -- & $\sqrt{ }$ & $\sqrt{ }$ \\
\hline 3 & Fani Suryani & -- & $\sqrt{ }$ & -- \\
\hline 4 & Anggi Lestari & $\sqrt{ }$ & $\sqrt{ }$ & -- \\
\hline 5 & Vira Oktapinda & -- & -- & $\sqrt{ }$ \\
\hline
\end{tabular}

Sumber : Hasil Penelitian, 2021

Tabel 2 menunjukkan secara ringkas bahwa menurut informan terjadi hambatan pada setiap perubahan pola komunikasi kerja pelayanan Customer Service selama pandemi Covid19. Masing-masing hasil wawancara telah dipaparkan dan telah diuraikan dipenjelasan sebelumnya. Selanjunya peneliti akan membahas tentang perubahan pola komunikasi cara kerja pelayanan Customer Service yang menimbulkan hambatan.

Pada penelitian ini, peneliti mengkaji dan menguraikan sesuai dengan hasil penelitian yang dilakukan pada Customer Service dan nasabah bank BJB KCP RSI Al-Ihsan. Peneliti memilih subjek penelitian yakni Customer Service dan nasabah karena menurut peneliti seorang Customer Service melakukan aktivitas komunikasi secara langsung dengan nasabahnya yang tidak bisa dilakukan dengan cara lain selama pandemi (pelayanan online). Maka dari itu, peneliti akan mengkaji seluruh hasil penelitian dengan menganalisa hasil penelitian dan diperkuat oleh teori-teori yang relevan.

Dari hasil wawancara diatas, berikut adalah pembahasan dan uraian tentang cara meningkatkan pola komunikasi pelayanan Customer Service selama pandemi Covid-19. Analisis perubahan tata letak ruang (layout) dan physical distancing sesuai teori proksemik. Perubahan tata letak ruang (layout) dilakukan karena adanya pandemi Covid-19 sehingga pelayanan Customer Service berubah dalam segi tata letak ruang dan jarak berkomunikasi antar karyawan dengan karyawan, karyawan dengan nasabah atau nasabah dengan nasabah. Istilah perubahan jarak yang digunakan selama pandemi Covid-19 adalah Physical Distancing. Physical distancing adalah peraturan yang mengharuskan setiap orang menjaga jarak setidaknya minimal 6 kaki atau 2 meter, physical distancing merupakan kebijakan pemerintah yang dikeluarkan menyusul adanya pandemi Covid-19 (Hidayat \& Rachmiatie, 2021). Hal ini memiliki tujuan agar dapat menekan penyebaran virus Covid-19 selama pelayanan berlangsung. Dalam teori proksemik atau teori jarak yang dikemukakan oleh Hall, 
proksemik adalah studi tentang sistematika keterlibatan seorang dalam struktur ruang, atau jarak antara manusia dalam pergaulan sehari-hari. Definisi tersebut sekaligus menggambarkan bahwa studi tentang ruang atau jarak berkaitan erat dengan interaksi antarmanusia yang berlandaskan pada ciri-ciri budaya tertentu (Nurul, 2020). Salah satu bentuk dasar jarak antarpribadi menurut Hall yakni Informal Space yang didalamnya terdapat empat konsep jarak: (a) Jarak Intim diperuntukan kepada dua orang yang berhubungan akrab, jarak tersebut $>46 \mathrm{~cm}$; (b) Jarak Pribadi diperuntukan bagi komunikasi antar dua orang pribadi, jarak tersebut $46 \mathrm{~cm}-122 \mathrm{~cm}$; (c) Jarak Kelompok diperuntukan jarak tubuh atau kedekatan badan dalam suatu kelompok atau ruang yakni $122 \mathrm{~cm}-366 \mathrm{~cm}$; (d) Jarak Publik yaitu jarak yang diperuntukan kepada sekelompok publik yakni $<366 \mathrm{~cm}$ (Nurul, 2020).

Berdasarkan pada teori proksemik yang sudah di uraikan pada paragraf sebelumnya bahwa jarak untuk melakukan komunikasi efektifnya adalah $46 \mathrm{~cm}-122 \mathrm{~cm}$, sedangkan dalam pelayanan Customer Service selama pandemi Covid-19 yang dalam pelaksanakannya menerapkan protokol kesehatan berupa physical distancing yang berjarak minimal $200 \mathrm{~cm}$. Hal ini dapat disimpukaan bahwa jika jarak dalam komunikasi pelayanan Customer Service sesuai dengan jarak physical distancing maka proses komunikasi tidak akan berjalan efektif. Mengutip dari salah satu pernyataan informan Customer Service, bahwa perlu adanya upaya memaksimalkan proses komunikasi selama pandemi Covid-19, meskipun diterapkannya physical distancing. Dalam proses pelayanan ini komunikasi akan berjalan efektif jika, Customer Service memperhatikan instrumen penting dalam penyampaian informasi seperti voice loudness yaitu kekuatan suara pada saat melakukan komunikasi antarpribadi atau dalam pelayanan Customer Service selama pandemi Covid-19.

Berikut adalah alur proses pelayanan komunikasi customer service bank BJB selama pandemi Covid-19:

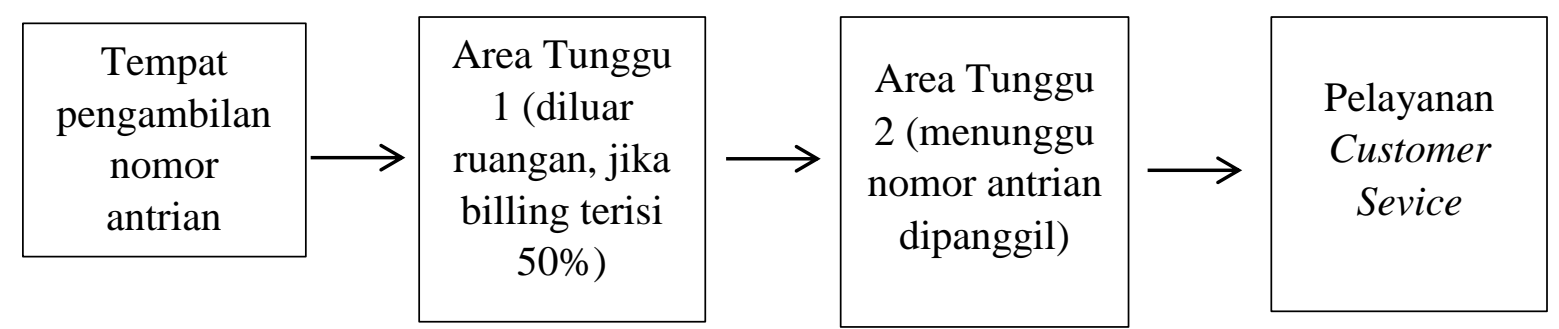

Gambar 1. Alur Proses Komunikasi Customer Service Bank BJB

(Sumber Hasil Penelitian, 2021)

Analisis durasi komunikasi pelayanan Customer Service bank BJB selama pandemi Covid-19 sesuai Teori Pesan. Durasi pada pelayanan Customer Service selama pandemi Covid-19 mengalami perubahan dari kondisi awal 30 menit untuk satu nasabah sekarang dipersingkat maksimal menjadi 15 menit untuk satu nasabah. Kondisi ini menuntut Customer Service sebagai komunikator harus memperpadat proses komunikasi dalam pelayanan dengan waktu yang terbatas. Komunikasi dilakukan dengan cara tatap muka, bentuk informasi verbal berupa suara dan media pendukung lainnya (komunikasi non-verbal) seperti saleskit atau informasi visual dalam bentuk brosur atau elektronik. Struktur 
menyampaikan informasi dalam pelayanan Customer Service dijelaskan dalam struktur pesan sebagai berikut, yakni: (a) Prologue, merupakan awalan komunikasi yang terjadi pada Customer Service dan nasabah berupa salam dan sapa; (b) Ask the Complaint, nasabah menjadi (komunikator) untuk mencerikan keluhan apa yang terjadi kepada Customer Service (komunikan); (c) Feedback, pada tahapan feedback ini Customer Service memberikan umpan balik kepada nasabah. selanjutnya Customer Service menjadi komunikator; (d) Evaluation \& Confirmation, Customer Service (komunikator) memberikan tanggapan dan memastikan saran tersampaikan kepada nasabah (komunikan); (e) Closing, akhir dari sesi pelayanan.

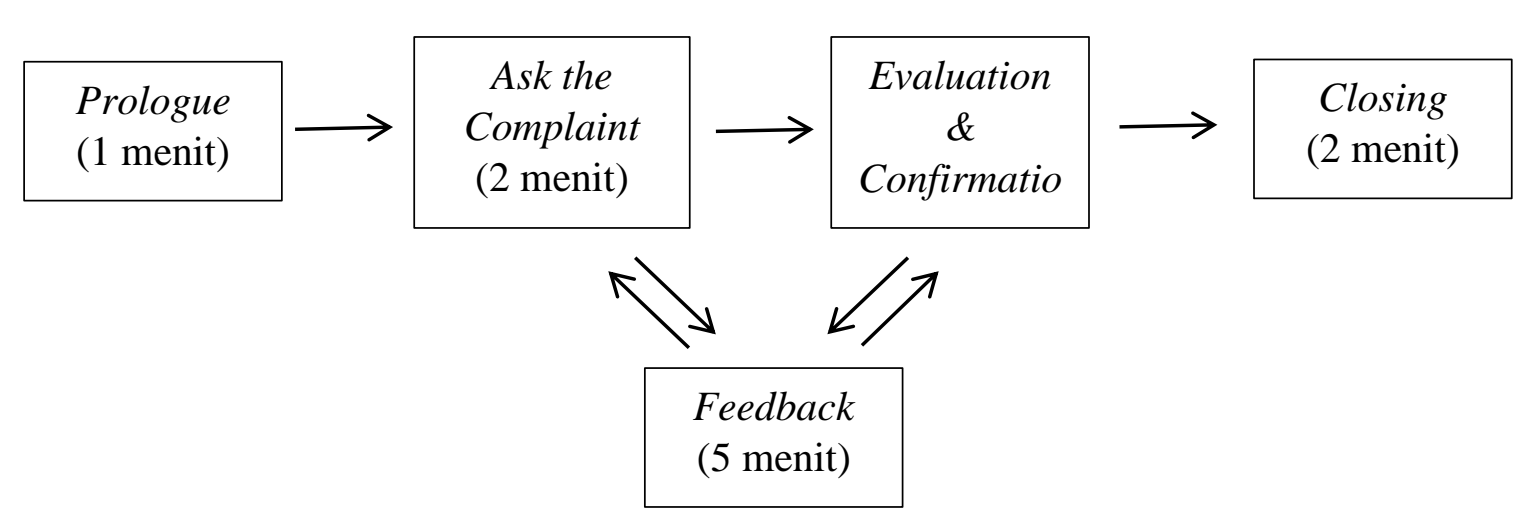

Gambar 2. Struktur Penyampaian Pesan

(Sumber : Hasil Penelitian, 2021)

Gambar 2 menunjukkan bahwa pada setiap tahapan dalam struktur penyampaian pesan memiliki durasi yang sudah ditentukan yaitu jumlah durasi dari semua tahapan selama 15 menit. Selaras dengan teori pesan yang disampaikan pada buku Konsep dan Aplikasi Ilmu Komunikasi bahwa Pesan adalah suatu komponen dalam komunikasi berupa paduan dan pikiran dari perasaan komunikator dengan menggunakan lambang atau bahasa lainnya yang disampaikan kepada orang lain (Mutialela, 2017). Hal ini berkaitan dengan konsep kredibilitas komunikator yang akan menentukan keberhasilan dari proses penyampaian pesan. Dalam kredibilitas komunikator oleh McCroskey terdapat tiga jenis yakni Kredibilitas Sumber, Kredibilitas Ekstrinsik dan Kredibilitas Instrinsik. Pada kredibilitas sumber terdapat tiga dimensi yaitu dimensi keotoritatifan adalah keahlian untuk menunjukan bagaimana komunikator membawakan pesan dengan subjek yang disajikan dan tentang kewibawaan komunikator dalam menyampaikan pesan. Selanjutnya, dimensi yang kedua yaitu watak atau karakter diartikan sebagai hubungan dengan tujuan dan maksud, dapat dilihat apakah komunikator bersifat obyektif, bermotivasi baik dan dapat dipercaya sehingga dapat di percaya dan disukai oleh komunikan. Terakhir yaitu dimensi kedinamisan, bagaimana keahlian komunikator dalam membujuk keaktifan dan motivasi dalam berbicara (Silvia \& Paramita, 2019).

Berdasarkan seluruh uraian diatas mengenai durasi pelayanan Customer Service selama pandemi Covid-19 yang mengharuskan Customer Service memperpadat pesan yang disampaikan dalam durasi yang sudah dipangkas maka sesuai dengan teori pesan yang 
beruhubungan dengan kredibilitas komunikator dimana didalamnya terdapat kajian menyeluruh tentang keahlian yang harus dimiliki oleh seorang Customer Service. Hal ini menjadi jawaban dari bagaimana cara melakukan pelayanan Customer Service meskipun durasi pelayanan di persingkat yaitu dengan memastikan bahwa Customer Service memiliki keahlian-keahlian yang sudah di rumuskan pada konsep kredibilitas sumber.

Analisis perubahan atribut Customer Service selama pandemi Covid-19 sesuai teori komunikasi non-verbal. Selain tata letak ruang (layout) dan durasi pelayanan yang berubah, penggunaan atribut Customer Service selama pandemi Covid-19 ikut mengalami perubahan berdasarkan dengan penerapan protokol kesehatan. Perubahan tersebut ditandai dengan adanya penambahan seragam baru yang harus digunakan oleh Customer Service berupa baju APD (Alat Pelindung Diri), masker medis dan sarung tangan standar bank. Tujuan penggunaan APD adalah untuk melindungi diri dan diharapkan agar dapat memutus rantai penularan virus Covid-19 selama pandemi. Pembahasan ini, peneliti memaparkan bahwa dalam tata cara penggunaan seragam Customer Service selama pandemi Covid-19 sebagai citra diri seorang Customer Service karena citra diri merupakan komponen dari komunikasi. Seperti yang dijelaskan oleh Bailey 2003, pandangan tersebut tentang citra diri adalah bersifat subjektif terhadap diri sendiri gambaran tubuh dan lain sebagainya. Penggunaan seragam tersebut adalah media penting dalam melakukan komunikasi terutama pada pelayanan Customer Service. Penggunaan seragam termasuk kedalam jenis komunikasi nonverbal artifaktual. Sesuai yang dikatakan Stone, mengemukakan bahwa pakaian adalah alat untuk menyampaikan pesan dapat dilihat sebelum kata-kata terdengar. Pesan yang dibawa oleh pakaian bergantung pada sejumlah variabel, seperti latar belakang, budaya, pengalaman dan sebagainya (Savira et al., 2017).

Dari uraian teori diatas dapat dilihat bahwa atribut Customer Service adalah unsur penting dalam komunikasi pelayanan Customer Service selama pandemi Covid-19, yang akan menggambarkan citra diri dari Customer Service itu sendiri dan menjadi media untuk menyampaikan pesan komunikasi non-verbal selama pelayanan berlangsung. Tantangan lain muncul pada saat pelayanan Customer Service menggunakan masker. sementara itu Customer Service harus tetap memberikan pelayanan yang informatif meskipun proses penyampaian komunikasi verbal terhalang oleh masker, maka dari itu Customer Service dapat menggunakan skills visual code yakni berkomunikasi dengan cara kontak mata sebagai upaya memaksimalkan tersampainya informasi (Nurul, 2020)

\section{PENUTUP}

Pola komunikasi pelayanan Customer Service selama pandemi Covid-19 terjadi perubahan pada segi tata letak ruang (layout) sehingga menimbulkan perubahan pada jarak berkomunikasi. Perubahan berikutnya adalah perubahan jam operasional yang menyebabkan durasi pelayanan Customer Service untuk satu nasabah di persingkat mengikuti peraturan jam operasional yang dipangkas karena adanya pandemi Covid-19 sehingga mengharuskan Customer Service menguasai kemampuan sebagai komunikator agar proses komunikasi dan penyampaian pesan tetap berjalan dengan lancer dan optimal. Perubahan terakhir pada pola komunikasi pelayanan Customer Service adalah perubahan atribut Customer Service. 
Perubahan ini terletak pada penggunaan APD (Alat Pelindung Diri) sebagai seragam baru, hal ini berkaitan dengan pesan non-verbal yang disampaikan lewat atribut atau pakaian.

Tujuan dilakukan semua perubahan pada pola komunikasi pelayanan Customer Service selama pandemi Covid-19 dan penerapan protokol kesehatan dari segala aspek pelayanan Customer Service adalah untuk memutus rantai penyebaran virus Covid-19 dan sebagai bentuk protection atau perlindungan terhadap diri sendiri. Namun disamping itu segala bentuk proses komunikasi pelayanan Customer Service dan penyampaian informasi harus tetap berjalan maksimal meskipun perubahan ini dilakukan.

Pada bagian ini, peneliti akan berusaha menyampaikan dan menguraikan saran yang diharapkan bermanfaat bagi semua pihak yang terkait dengan permasalahan penelitian ini sebagai berikut, (1) Kepada para peneliti selanjutnya yang akan melakukan penelitian yang serupa diharapkan dapat melanjutkan dan mengembangkan lagi penelitian tentang bagaimana komunikasi harus tetap berlangsung dengan baik dalam proses pelayanan Customer Service selama pandemi Covid-19. (2) Dalam hal ini diharapkan juga masyarakat dan nasabah harus memiliki kesadaran yang penuh tentang penerapan protokol kesehatan sehingga hal ini tidak menjadi hambatan dikemudian hari. (3) Diharapkan adanya peningkatan pelayanan pada Customer Service secara teknis agar menghindari terjadinya misscomunication diwaktu selanjutnya.

\section{REFERENSI}

Adi, R. (2017). HUBUNGAN ANTARA KECANDUAN GADGET (SMARTPHONE) DENGAN EMPATI PADA MAHASISWA FAKULTAS PSIKOLOGI UNIVERSITAS MUHAMMADIYAH SURAKARTA (Vol. 87, Issue 1,2).

Ajif, P. (2013). Pola Jaringan Sosial pada Industri Kecil Rambut Palsu di Desa Karangbanjar, Kecamatan Bojongsari, Kabupaten Purbalingga. Jurnal Penelitian, 3140. https://eprints.uny.ac.id/18100/5/BAB III 09.10.033 Aji p.pdf

Alnsour, M. S. (2013). How to Retain a Bank Customer: A Qualitative Study of Jordanian Banks Relational Strategies. International Journal of Marketing Studies, 5(4), 123-131. https://doi.org/10.5539/ijms.v5n4p123

Andhini, N. F. (2017). Pemberian reward dan punishment. Journal of Chemical Information and Modeling, 53(9), 1689-1699.

Blery, E., \& Michalakopoulos, M. (2006). Customer relationship management: A case study of a Greek bank. Journal of Financial Services Marketing, 11(2), 116-124. https://doi.org/10.1057/palgrave.fsm.4760014

Fay, D. L. (1967). Angewandte Chemie International Edition, 6(11), 951-952.

Handayani, D., Hadi, D. R., Isbaniah, F., Burhan, E., \& Agustin, H. (2020). Corona Virus Disease 2019. Jurnal Respirologi Indonesia, 40(2), 119-129. https://doi.org/10.36497/jri.v40i2.101

Hendrawan, A., Sucahyowati, H., \& Laras, T. (2020). AmaNU : Jurnal Manajemen dan 
Ekonomi Suwono AmaNU: Jurnal Manajemen dan Ekonomi AmaNU: Jurnal Manajemen dan Ekonomi Suwono AmaNU: Jurnal Manajemen dan Ekonomi. Manajemen Dan Ekonomi, 3(1), 55-72.

Hidayat, D. (2012). Komunikasi Antarpribadi dan Medianya. http://digilib.fisipol.ugm.ac.id/handle/15717717/16296

Hidayat, D., \& Rachmiatie, A. (2021). Construction of Social Reality for Physical Distancing During the COVID-19 Pandemic. Komunikasi, 13(1), 10-19.

Ii, B. A. B., \& Teori, A. K. (n.d.). Mohammad Shoelhi, Komunikasi Internasional Perspektif Jurnalistik (Bandung: Sembiosa Rekatama Media, 2004), hlm.2. 17 11. 11-31.

Khoirudin, A., \& Hafizd, J. Z. (2020). Pendampingan Operasional Bank Syariah Di Masa Pandemi Covid-19. Dimasejati: Jurnal Pengabdian Kepada Masyarakat, 2(2), 250. https://doi.org/10.24235/dimasejati.v2i2.7330

M. Ja'far, S. S., \& Itsnaini, P. raudhatul. (2020). Dampak Covid-19 terhadap Lembaga Keuangan Syariah (PERBANKAN SYARIAH). Bank Syariah Jafar, 1-17.

Margianti. (2017). Implementasi Service Excellence Oleh Customer Service Pada Bank BNI Syariah KCP Bandar Jaya. 5-95.

Maulana, M. A. (2021). Implikasi Covid-19 Terhadap Customer Relationship Management Pada Pembiayaan.

Mawarni, R., \& Iqbal Fasa, M. (2021). Optimalisasi Kinerja Digital Banking Bank Syariah di Masa Pandemi Covid-19. Jurnal Manajemen Bisnis (JMB), 34(1), 1-13. http://ejournal.stieibbi.ac.id/index.php/jmb

Mustika, N. (2017). ANALISIS PENGARUH CUSTOMER RELATIONSHIP MANAGEMENT TERHADAP LOYALITAS PELANGGAN DALAM PERSPEKTIF ETIKA BISNIS ISLAM (Studi Pada Bengkel AHASS (Astra Honda Authorized Service Station) Bintang Kharisma Jaya Bandar Lampung). (Doctoral Dissertation, UIN Raden Intan Lampung)., 14-50.

Mutialela, R. (2017). KONSEP DAN APLIKASI ILMU KOMUNIKASI.

Nursalam, 2016, metode penelitian, \& Fallis, A. . (2013). Pengertian Customer Service. Journal of Chemical Information and Modeling, 53(9), 1689-1699.

Nurul, D. (2020). Komunikasi Non Verbal Penyampaian Komunikasi. 1-5.

Rostami, A., Amir Khani, A. H., \& Soltani, G. (2016). The Impact of E-service Quality on the Improvement of the Level of Communication with Customers of Bank Melli Branches in South Tehran Affairs Office. Procedia Economics and Finance, 36(16), 448-455. https://doi.org/10.1016/s2212-5671(16)30063-6

Saputra, M. I. (2013). Pola Komunikasi Islam Penyuluh Dalam Pencegahan Dan Pemberantasan Bahaya Penyalahgunaan Narkoba Di Kalangan Remaja Kota Langsa. 
$\begin{array}{lllll}\text { Filsafat Ilmu } \quad \text { Komunikasi } & \text { Suatu }\end{array}$ http://repository.uinsu.ac.id/1109/5/Bab II.pdf

Savira, F., Suharsono, Y., Tamrat, W., Pasimeni, F., Pasimeni, P., Kecerdasan, I., Ikep, P., Shahan, A., Jahan, F., Samuels, R., Group, W. B., Charles, L. E., 中島, Smoke, P., Simplice, A., Libâneo, J. C., Lindblom, C. E., Bilney, C., Pillay, S., ... LEMES, S. de S. (2017). Komunikasi Non Verbal. Journal of Chemical Information and Modeling, 21(2), 1689-1699. https://www.oecd.org/dac/accountable-effectiveinstitutions/Governance Notebook 2.6 Smoke.pdf

Silvia, S., \& Paramita, S. (2019). Kredibilitas Komunikator Dalam Menyampaikan Pesan (Analisis Opini Generasi Milenial Pada Kepala Penerangan Kodam Jaya). Koneksi, 2(2), 569. https://doi.org/10.24912/kn.v2i2.3938

Tahliani, H. (2020). Tantangan Perbankan Syariah dalam Menghadapi Pandemi Covid-19. Madani Syari'ah, 3(2), 92-113. https://stai-binamadani.ejournal.id/Madanisyariah/article/view/205

Tery dan Franklin. (2003). Pengertian Komunikasi Kajian Pustaka. Journal of Chemical Information and Modeling, 52. http://repository.unpas.ac.id/11586/5/BAB 2.pdf

Wahdian, \& Setiawati, S. D. (2020). Customer Relationship Management Pt. Samsung Electronics Indonesia Di Tengah Pandemi Covid-19 Di Indonesia. Linimasa: Jurnal Ilmu Komunikasi, 3(2), 55-66. http://www.journal.unpas.ac.id/index.php/linimasa/article/view/2778

Widyasari, Y. (2020). Strategi Komunikasi Yang Efektif Pada Customer Service Dalam Meningkatkan Kepuasan Nasabah Pt Bank Central Asia Tbk (Bca) Kcu .... Danum Pambelum: Jurnal Pendidikan Dan https://ejournal.iaknpky.ac.id/index.php/DP/article/view/14

Yolanda, R. F. (2020). Strategi Pelayanan Prima Customer Service Perspektif Bisnis Islam Di Bprs Kotabumi Institut Agama Islam Negeri ( Iain ) Metro 1441 H 2020 M Strategi Pelayanan Prima Customer Service Institut Agama Islam Negeri ( Iain ) Metro. 